\title{
Forests Policies and Programmes in India: Implications for Climate Change Adaptation
}

\author{
Indu K. Murthy, ${ }^{1,2}$, Poornima Kumar ${ }^{1,3}$ \\ ${ }^{1}$ Centre for Sustainable Technologies, Indian Institute of Science, Bengaluru, India \\ ${ }^{2}$ Department of Ecology and Environment, Pondicherry University, Pondicherry, India \\ ${ }^{3}$ Centre for Study of Science, Technology and Policy, Bangalore, India \\ Email: indumurthy@iisc.ac.in, poornimakumar275@gmail.com
}

How to cite this paper: Murthy, I. K., \& Kumar, P. (2019). Forests Policies and Programmes in India: Implications for Climate Change Adaptation. Open Journal of Forestry, 9, 226-240.

https://doi.org/10.4236/ojf.2019.93012

Received: May 17, 2019

Accepted: July 20, 2019

Published: July 23, 2019

Copyright $\odot 2019$ by author(s) and Scientific Research Publishing Inc. This work is licensed under the Creative Commons Attribution International License (CC BY 4.0).

http://creativecommons.org/licenses/by/4.0/

CC) $\underset{\mathrm{EY}}{\mathrm{EY}}$ Open Access

\begin{abstract}
Climate change is a major global environmental and developmental challenge and climate proofing of vulnerable sectors, programmes, natural systems and communities by integrating adaptation and mitigation options into planning process are increasingly becoming an integral part of development. The basic premises on which this could happen are the national and sectoral policies that govern any programmes and actions implemented on ground. This study reviews existing policies, plans and programmes and their implications for climate change. Based on the analyses, key areas of research, policy initiatives and institutional and capacity development needs have been identified, to facilitate climate change adaptation. The forest policies formulated so far in India have been broadly aimed at conservation, reduction of pressure on forests and provisioning of biomass to the large forest dependent population for their fuel and fodder needs apart from generating revenue through production and sale of timber. However, these have not been formulated with climate change as a consideration and therefore may become less effective as climate change and its impacts become increasingly evident. The study clearly identifies that the current policies and programmes have elements/features and activities that directly or indirectly contribute positively towards adaptation, although the primary implications are towards biodiversity and to some extent ecosystem functioning. It finally highlights the need for incorporating climate change concerns in forest sector development programmes and also to address the issue of climate change.
\end{abstract}

\section{Keywords}

Forest Sector, Climate Change, Adaptation, Forest Policies, Programmes, 


\section{Introduction}

Climate change is a major global environmental and developmental challenge and is an issue of great concern to all countries and regions irrespective of their size or level of development. Although a lot on climate change and the related impacts are yet to be understood, it is now unequivocally established through global scientific assessment that climate change is "happening" and it is happening at a brisk pace. A study by MoEF (2010) in India has highlighted the severity of the impact of climate change on food production, water resource availability, forest biodiversity, and coastal zones, even in the short-term period of 2030s.

India's National Action Plan on Climate Change maintains categorically that "climate change may alter the distribution and quality of India's natural resources and adversely affect the livelihood of its people. With an economy closely tied to its natural resources base and climate-sensitive, sectors such as agriculture, water and forestry, it may face a major threat". The above concerns on the degree of climate vulnerability of the various natural resource sectors and large sections of society make a stronger case for government "planned adaptation" interventions. Further, mitigation actions take considerable amount of time to take effect and under such circumstances, adaptation is the only choice to cope with climate variability and climate change.

The Stern Report (2006) has confirmed the proposition that "the benefits of strong, early action on climate change outweigh the costs". According to IPCC, adaptation is well-thought-out effective tool to address various impacts resulting from warming, already unavoidable due to bygone emissions and emerging emissions that go unchecked. More recently, the World Economic Forum (2016) published a report stating that climate change was among the top global economic threats. Hence, there is a need for government driven "planned" adaptation measures, policy framework and strategies, and subsequently its specific as well as larger implementation. In light of the Paris Agreement brought into force, which places particular emphasis on balancing GHG emissions by sources and removals by sinks, and REDD+, examining the state of forest policy and programmes in India is particularly pertinent.

Given the inherent costs involved, adaptation should be pursued not as an end in itself, but as a means to meet the development objectives, by factoring in climate risks in development planning and considering a range of interventions that will increase their resilience to climate change. Climate proofing of vulnerable sectors, programmes, natural systems and communities by integrating adaptation and mitigation options into planning process and interventions are increasingly becoming an integral part of development. The basic premises on which this could happen are the national and sectoral policies that govern any 
programmes and actions implemented on ground.

\section{Current Climate Variability and Long-Term Climate Change: Implications for Conservation and Management of Forests}

India is currently on an accelerated growth and development pathway. These changes have been possible because of the government's firm commitment to an agenda of development that is inclusive. To fulfill this agenda, the government had not only utilized its limited resources prudently but had also strengthened its administrative machinery and introduced a number of institutional reforms, to ensure that growth is a long-term stable process. However, climate change is a major issue that needs to be taken into consideration when planning and implementing developmental goals and programmes. Herein we discuss the vulnerability of forest ecosystems to climate change.

Forest ecosystems are intrinsically dynamic and are constantly influenced by climatic variations and can adapt to the changes in the environment. However, climate change is expected to occur more rapidly than the rate at which ecosystems can adapt and reestablish themselves. It has been pointed out (Betts et al., 2008) that tropical forests are vulnerable to climate change and its impacts on them could be so severe as to threaten their structure, function and services. The fourth as well as the fifth assessment report of IPCC $(2007,2014)$ concludes that forest ecosystems could be seriously impacted by future climate change, even with moderate global warming of $1^{\circ} \mathrm{C}$ to $2^{\circ} \mathrm{C}$. In keeping with this, the Paris Agreement stipulates a target of restricting global average temperature increase to well below $2^{\circ} \mathrm{C}$ above pre-industrial levels, and to attempt to restrict this to $1.5^{\circ} \mathrm{C}$ (UNFCCC, 2015).

Impacts of climate change on forest ecosystems are varied and include both direct and indirect impacts. Direct impacts or consequences of climate change include: changes in ecosystem functioning; impacts on species interactions, species abundance, biodiversity, wildlife range distribution; implications for pests and diseases and invasive species. Indirect impacts encompass human-wildlife conflicts and implications to forest dependent communities.

According to the fifth assessment report of the IPCC (2014), "successful adaptation will depend on our ability to allow and facilitate natural systems to adjust to a changing climate, thus maintaining the ecosystem services on which all life depends". Although adaptation to climate change is high on the agenda of several institutions, very little has yet been done on developing any set of practical and strategic interventions specific to a bio-geo-social context. India's recent climate pledges have made it clear that going forward, adaptation will be a major national priority. India's NDC lists planned afforestation as a key goal, with a target of "eventually" increasing forest cover to 33 percent of the country's geographical area.

Ultimately, policy-makers can choose from a wide range of interventions to adapt to climate change and reduce disaster risk, including "soft", "hard" or "hybrid" options to adapt to climate change and reduce disaster risks $(\mathrm{CBD}$, 
2018). "Soft options" include policy frameworks and are fundamental to any programme being implemented on the ground and also determine "hard" or "hybrid" options to be adopted for conserving, managing or restoring ecosystems that provide services critical to reducing risks and impacts, including forest ecosystems.

In view of the above, this paper critically analyses existing forest policies, and climate change actions undertaken for their scope to address climate variability and climate change related issues in India.

\section{Forest Policies and Programmes: Implications for Adaptation to Climate Change}

Forests in India are governed by policies, formulated by the Government of India. The issues related to forest and environment management are given adequate importance in the overall policy and planning for balanced development of the country. The basic approach is development without destruction, which is evident from the Constitution of the country, the fountainhead of all national laws. It provides space for dealing with matters related to environment and forest. The subject of forestry falls in the Concurrent List of Schedule VII of the Constitution, thereby empowering both the Central Government and State Government to legislate on the subject in the interest of citizens of the country, and with a view to protecting country's environment and ecology.

India has an effective legal and policy framework guiding and directing the sustainable management of forests. In this section, the principle objectives of these legislations have been stated in brief so that their relevance to, and synergy with adaptation for addressing issues arising from climate variability and long-term climate change may be appreciated fully.

Forest Policy of 1894: The first, and major, forest policy in India was formulated in 1894. It was drawn after the Forest Department had demarcated, surveyed and mapped the forest area of India. The goals of the policy were: a) to lay down certain general principles of forest management, $b$ ) to formulate a forest policy that would serve agricultural interests more directly, c) to maintain forests primarily for preservation of the climatic and physical conditions, and d) to fulfill the needs of the people. The forests were classified to reflect these objectives, according to their primary functions, into: forests where preservation was essential on climatic and physical grounds, forest for extraction of valuable timber for commercial purpose, and forests for use by community and as pasturelands. Further, forest classification was based on the quality of forests; $47 \%$ as Reserve forest, $30 \%$ as protected forest and $22 \%$ as unclassified forests.

Indian Forest Act, 1927: This is a country-wide Act to consolidate the law relating to forests, the transit of forest-produce and the duty leviable on timber and other forest-produce.

National Forest Policy of 1952: The Forest Policy of 1952 was initiated to allow exclusive state control over forests and its management. The policy aimed to increase government control over forest resources and develop forests to meet 
the timber needs of industry and defense. It declared that village communities should not be permitted to exercise their traditional rights over the forests at the expense of national interest.

Wildlife Protection Act, 1972: The Wildlife Protection Act was passed in 1972 and subsequently revised in 2002 and 2006. The goals of the Act are; to ensure protection of wild animals and to declare forests and habitats of wild animals as sanctuaries and national parks. The Wild Life (Protection) Amendment Bill, 2002 was proposed to enhance penalties for violation of the provisions of the Act. It also proposed to create two new categories of Protected Areas, viz., "Conservation Reserve" and "Community Reserve".

Forest Conservation Act, 1980: The Forest Conservation Act of 1980 was enacted to regulate reduce or ban indiscriminate diversion of forestland for non-forestry purposes and, to regulate and control forestland use change. Forest conversion is banned or regulated under the Act, effectively reducing deforestation. All forest conversion to non-forestry purposes has to be cleared by the Central Government as per this Act. If conversion is approved, then raising of compensatory plantations is mandatory.

Social Forestry (post-1980): The National Commission on Agriculture (NCA), 1976 suggested the setting up of a corporation to manage forests and to attract monetary assistance from various government and non-government sources. As a result, autonomous forest corporations were started, and large-scale plantation activities began. The NCA report also suggested initiation of the social forestry programme on non-forestry lands such as village commons, government wastelands and farmlands to reduce pressure on forests. Social Forestry is India's as well as one of the worlds' largest afforestation programmes and has covered more than 28 Mha. Survival rate of seedlings in plantations at the national level was $77 \%$. Productivity recorded in farm forestry is $4.2 \mathrm{t} / \mathrm{ha} /$ year and in Forest Department plantations, $2.6 \mathrm{t} / \mathrm{ha} /$ year (Seabauer, 1992).

The Forest Policy of 1988: The forest policies hitherto emphasized the importance of protecting forests, which are places of high faunal and floral diversity and national heritage sites. However, the success of several experiments in West Bengal and Haryana on participatory forestry encouraged the government to include local people in forest management (Poffenberger \& Singh 1996; Ravindranath et al., 1997; Saxena, 1997). The policy aims for maintaining one-third of the country's geographical area under forest and tree cover and calls for massive afforestation and social forestry programmes with people's participation for increasing the forest and tree cover in the country.

Joint Forest Management Resolution of 1990: Afforestation programme under social forestry was dominated by monocultures of exotic species such as Acacia auriculiformis, A. mangium, Eucalyptus, Casuarina, etc., with minimal participation of local community and with Forest Department wholly implementing the programme. One of the major criticisms of the social forestry programme was that it did not meet its objectives such as meeting diverse biomass needs and participation of local communities. Thus, efforts were initiated to enhance forest 
cover through participatory process where people protect forests and derive benefits through the Joint Forest Management (JFM) programme. The policy aims at recognition of rights of organized communities over a clearly defined degraded patch of the forest. State level resolutions have legitimized JFM activities at all levels-from the state Forest Departments to the village communities.

Biological Biodiversity Act, 2002: The Act provides for conservation of biological diversity, sustainable use of its components and fair and equitable sharing of the benefits arising out of the use of biological resources knowledge and for matters connected therewith or incidental thereto.

National Environment Policy, 2006: This policy which builds on the existing policies related to preservation of natural resources is intended to guide action in developing regulatory reforms, and programmes and projects for environmental conservation by the Central and State Governments. The policy emphasizes partnership of different stakeholders.

National Agro-forestry Policy. The National Agro-forestry Policy (NAP) of India, the first of its kind in the world, aims at encouraging and expanding tree plantation in complementarity and integrated manner with crops and livestock. It is aimed to help protect and stabilize ecosystems and promote resilient cropping, and farming systems to minimize risks of extreme climatic events and complement in achieving India's target of increasing forest/tree cover.

The Schedule Tribes and Other Traditional Forest Dwellers Act, 2006: This is the important Act to recognize and vest the forest rights and occupations in forest land in forest dwelling Scheduled Tribes and other traditional forest dwellers who have been residing in such forests for generations but whose rights could not be recorded; and to provide for a framework for recording the forest rights so vested and the nature of evidence required for such recognition and vesting in respect of forest land.

Intended Nationally Determined Contribution (INDC): The Paris Agreement, which was drafted at CoP21, entered into force on November 4, 2016 when 55 countries accounting for 55 percent of global emissions ratified it. Prior to CoP21, India submitted its Intended Nationally Determined Contributions, which were ratified when it ratified the Paris Agreement in October 2016. Its Nationally Determined Contribution (NDC) includes a target of creating an additional carbon sink of additional carbon sink of 2.5 to 3 billion tonnes of $\mathrm{CO}_{2}$ equivalent through additional forest and tree cover by 2030. Additionally, the Paris Agreement itself emphasizes the importance of REDD+ and creating a balance between GHG sources and sinks towards achieving global climate goals.

\subsection{Implications of Current Policies to Climate Change Adaptation}

Most forest policies were not formulated with climate change in mind. Such policies may become less effective as climate change and its impacts become increasingly evident and may inadvertently increase societal and resource vulnerability to climate change by creating barriers to adaption. Table 1 presents the 
Table 1. Forest policies, their features and implications for climate change adaptation.

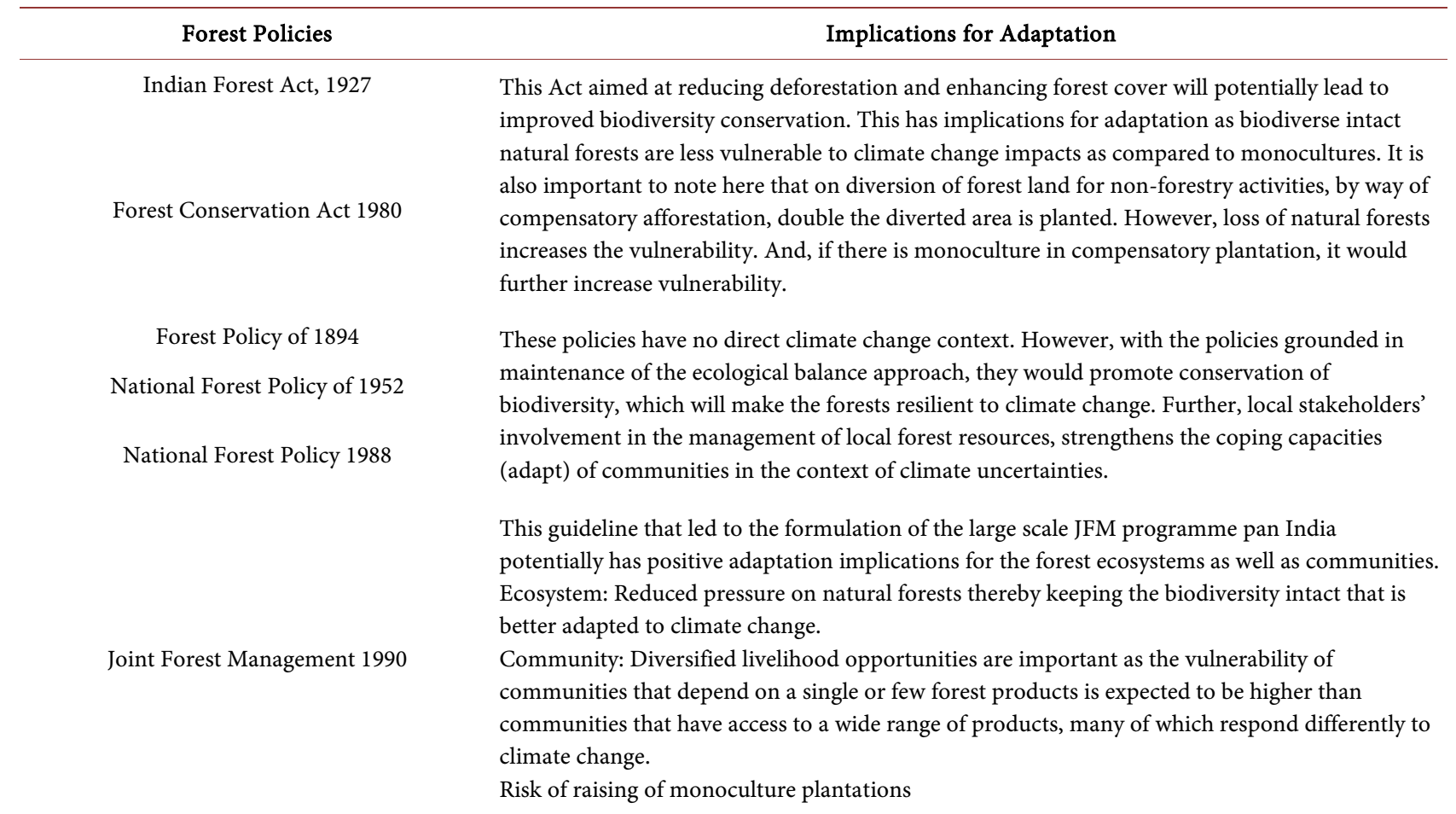

Wildlife Protection Act (WCS) 1972

National Wildlife Action Plan 1983

National Biodiversity Act 2002

Forest Rights Act 2006

Social Forestry (post-1980)

National REDD+ Policy, 2014
Recommends strict conservation zones free of all habitations and modern day facilities, tourism, etc., critical for avoiding habitat fragmentation and degradation. Has the potential to promote adaptation. Protection from fire, control of invasive species (through habitat improvement measures) and maintaining ecosystem and biodiversity values also support elements of climate change mitigation.

Promotes conservation of biodiversity and biodiverse natural forests are better adapted to climate change and resilient to attack by pests and fire.

Recognizes the rights of forest dependent communities and provides opportunity for utilization of local knowledge for forest management and adaptation.

This Act legalizes human activity inside forests which may have negative impacts on regeneration due to increase disturbance through grazing, land use change, etc. This potentially can increase the vulnerability of forests to climate change.

Predominated by monocultures in the past, therein making single species stands or plantations vulnerable to pest attack and fire, one of the larger impacts of a changing climate.

Intended to provide incentives to local forest communities to protect forests (carbon sinks).

key features of some of the forest policies of India that determine the way forests are managed and conserved. It also analyses the implications of these policy features for management and conservation of forests under a variable and changing climate.

Mitigation and adaptation are two approaches identified for addressing climate change. Climate adaptation refers to the ability of a system to adjust to climate change (including climate variability and extremes) to moderate potential damage, to take advantage of opportunities, or to cope with the consequences. The IPCC defines adaptation to climate change as adjustment in natural or human systems in response to actual or expected climatic stimuli or their 
effects, which moderates harm or exploits beneficial opportunities. Adaptation is necessary not only for the projected changes in climate but also because climate change is already affecting many ecosystems and there is a need to cope with the current climate variability.

The forest policies formulated so far in India have been broadly aimed at conservation, reduction of pressure on forests and provisioning of biomass to the large forest dependent population for their fuel and fodder needs apart from generating revenue through production and sale of timber. The policies have evolved over the decades and the shift in focus from production forestry to protection forestry and currently participatory forestry is evident. The policies that kept communities outside forests have evolved over the decades to involve them in planning and management of forests. Herein some of the key policies discussed in Section 2 are analysed for elements or features that could potentially promote adaptation or increase the vulnerability of forests and forest dependent communities.

As can be seen from Table 1, most of the policies have provisions for conservation, promotion of biodiversity, arresting deforestation, catering to the biomass needs of local communities and promoting participation of local communities in forest management. However, some of these features also promote adaptation by help conserve the ecosystem structure and function as discussed below:

1) Conservation of ecosystem structure and function is an important climate change adaptation strategy because species and genetically rich ecosystems have a greater potential to adapt to climate change. Available scientific evidence strongly supports the conclusion that the capacity of forests to resist change, or recover following disturbance, is dependent on biodiversity at multiple scales. Further, maintaining and restoring biodiversity in forests promotes their resilience to human-induced pressures and is therefore an essential "insurance policy" and safeguard against expected climate change impacts (Thompson et al., 2009).

The forest policies such as the Forest Conservation Act and the Biodiversity Act in their mandate have elements that clearly contribute positively towards adaptation in forest ecosystems by ensuring the diversity of species are conserved, maintained and enhanced. Further, it is important to mention here that the Wildlife (Protection) Act, 1972 mandates conservation of habitat and biodiversity therein, having strong positive elements of adaptation.

2) The resilience of a forest ecosystem to changing environmental conditions is determined by its biological and ecological resources, in particular 1) the diversity of species, 2) the genetic variability within species, and 3) the regional pool of species and ecosystems and for a given ecosystem, functionally diverse communities are likely to be better able to adapt to climate change and climate variability than impoverished ones.

Policies such as the Wildlife Protection Act that is intended to conserve habitats by halting degradation and keeping a check on fragmentation contribute to adaptation. 
3) Resilience is influenced by the size of forest ecosystems (generally, the larger and less fragmented, the better), and by the condition and character of the surrounding landscape. Policies such as the Forest conservation Act, National Biodiversity Act and the overarching National Forest policy are all aimed at maintaining the diverse natural forests and the forest cover. Such policies and measures that promote protection of natural forests yield both biodiversity conservation and climate change benefits, in addition to a full array of ecosystem services.

4) The JFM Guidelines that paved the way for participation of local communities in forest management have the potential to promote adaptation in participating forest dependent communities. The promotion of community forestry in many developing countries may increase local adaptive capacity by putting decisions in the hands of the people who feel the effects of climate change first, and by enhancing the role of traditional knowledge in forest management (Gyampoh et al., 2009).

5) Native primary forests are resilient as well as adaptive to changes in climate and other disturbances, compared to man-made plantations. This is primarily because of greater biodiversity in native forests. Further, the quality of a site prior to raising plantations will determine its value and site characteristics would determine if there are positive negative or neutral effects on biodveristiy, when plantations are raised. According to Thompson et al., 2009, reforestation of degraded lands will often produce the greatest benefits to biodiversity but can also provide the greatest challenges to forest management.

Thus, many of the policies contribute positively to adaptation or enhancing resilience of forest ecosystems. However, policies that promote afforestation may lead to increased vulnerability, if large-scale monocultures of exotic species are promoted. Social forestry and JFM guidelines promote plantation activities and these if not implemented taking into consideration the biodiversity and indigenous species could lead to increased vulnerability. It is imperative to understand that plantations of native tree species will usually support more biodiversity than exotic species and plantations of mixed tree species will usually support more biodiversity than monocultures.

\subsection{Implications of Current Forestry Programmes to Climate Change Adaptation}

Table 2 presents some of the forestry programmes implemented and also discusses the key features of these programmes and its implications for climate change mitigation and adaptation. As can be seen from Table 2, all the programmes contribute to conservation and at the same time lead to building of resilience in the communities' dependent on them or the forest ecosystem itself by conserving biodiversity which is one of the key factors determining the resilience of forest ecosystems. It is evident from Table 2 that many of the ongoing forestry programmes currently have positive implications for adaptation and even the proposed Greening India Mission is targeted towards promoting adaptation. 
Table 2. Features of forestry programmes and implications for adaptation to climate change (adapted from ACT, 2016).

\begin{tabular}{|c|c|c|}
\hline Programmes & Features & Implications for Adaptation \\
\hline Greening India Mission & $\begin{array}{l}\text { Enhancing carbon sinks in sustainably managed forests } \\
\text { and other ecosystems. } \\
\text { Enhancing resilience of vulnerable species/ecosystems } \\
\text { to changing climate. } \\
\text { Enabling adaptation of forest-dependent communities } \\
\text { to climatic variability. }\end{array}$ & $\begin{array}{l}\text { Promotes ecosystem as well as community resilience } \\
\text { through targeted activities for promoting adaptation } \\
\text { through regeneration, restoration, tree cover } \\
\text { enhancement that help connect forest fragments and also } \\
\text { promotes livelihood diversification activities, which } \\
\text { reduces the vulnerability of forest dependent communities. } \\
\text { Promotion of exotic species and monoculture plantations } \\
\text { may enhance the vulnerability. }\end{array}$ \\
\hline $\begin{array}{l}\text { National Forest Action } \\
\text { Plan } 1999\end{array}$ & $\begin{array}{l}\text { Protect existing forest resources. } \\
\text { Improve forest productivity. } \\
\text { Reduce total demand for biomass. } \\
\text { Strengthen the policy and institutional framework. } \\
\text { Expand the forest area. }\end{array}$ & $\begin{array}{l}\text { Conservation and protection of forest resources, thereby } \\
\text { biodiversity which has positive implications for climate } \\
\text { change adaptation. }\end{array}$ \\
\hline $\begin{array}{l}\text { National Afforestation } \\
\text { Programme }\end{array}$ & $\begin{array}{l}\text { Develop forest resources with people's participation, } \\
\text { with focus on improvement in livelihoods of } \\
\text { forest-fringe communities. } \\
\text { Aims to accelerate the on-going process of devolving } \\
\text { forest protection, management and development } \\
\text { functions to decentralized institutions. }\end{array}$ & $\begin{array}{l}\text { Improved participation of communities in management of } \\
\text { forests, thereby providing an opportunity for utilizing } \\
\text { strategic indigenous knowledge on adaptation. } \\
\text { Inappropriate choice of species such as exotics/invasive } \\
\text { species may increase vulnerability. }\end{array}$ \\
\hline Protected Areas & $\begin{array}{l}\text { The NFP has advocated maintaining genetic continuity } \\
\text { among the Protected Areas. The Wildlife Protection } \\
\text { Act has included two categories of PAs, namely } \\
\text { conservation and community reserves in its } 2002 \\
\text { amendment. }\end{array}$ & $\begin{array}{l}\text { PAs are key to buffering unpredictable impacts of } \\
\text { impending climate change as they help retain intact } \\
\text { patches of forest, avoiding fragmentation which is an } \\
\text { adaptation strategy. PAs also aim at conserving biodiversity } \\
\text { and ecosystems, which is also an adaptation strategy. Also, } \\
\text { protection measures against fire and invasive species and } \\
\text { habitat amelioration interventions are additionally climate } \\
\text { change mitigation measures. }\end{array}$ \\
\hline Compensatory Afforestation & $\begin{array}{l}\text { In case of diversion of forest land to non-forest } \\
\text { purposes-the user will identify land and develop } \\
\text { forest and transfer it to forest dept. or pay the cost of } \\
\text { afforestation ( } 2 \text { ha of afforestation for every ha of forest } \\
\text { converted). }\end{array}$ & $\begin{array}{l}\text { Conservation, protection and improved regeneration } \\
\text { would potentially reduce vulnerability. } \\
\text { Risk of monocultures raised being prone to fire and pest } \\
\text { attacks. } \\
\text { Risk of loss of natural forests with biodiversity and } \\
\text { livelihood values. }\end{array}$ \\
\hline
\end{tabular}

It is also important to note that agro-forestry is listed as one of the strategies for mitigation and adaptation of climate change in India's Nationally Determined Contributions.

Specifically, programmes such as Protected Area Management and Joint Forest Management have potential to contribute positively to sink creation and conservation as a mitigation option and to improving the resilience of the forest ecosystems, and the communities' dependent on them. Agro-forestry, tree conservation programme and soil moisture conservation works carried out in addition to rehabilitation of degraded forests are also activities clearly identified by the Greening India Mission under the National Action Plan for Climate Change and the NDC and could contribute positively to adaptation. Agro-forestry systems have substantial potential to sequester carbon and can reduce soil erosion, moderate climate extremes on crops, improve water quality, and provide goods 
and services to local people (Lovejoy \& Hannah, 2005).

The important factor to be taken into consideration in the afforestation programmes is promotion of native and mixed species forestry, to ensure they are positive adaptation strategies as well (ACT, 2016).

\section{Issues Unaddressed in the Current Forest Policies and Programmes}

The policies and programmes discussed in the previous sections, primarily have implications for biodiversity and to some extent on ecosystem functioning. However, none of the programmes or policies address the following some of the issues or consequences of climate related variability and changes, and the same is discussed in this Section.

Habitat and range shifts. Most plants and animals prefer to live in a particular habitat with a specific temperature range and amount of precipitation. Climate change will alter, and in some cases, destroy, certain types of habitats. Some species will be able to adapt to changing habitats-for example, by shifting their range northward or to higher altitudes in order to adjust to rising temperatures. Others, however, might not be able to adapt fast enough to keep pace with the rate of climate change (US-EPA, 2010).

A changing climate forces plants and animals to migrate in order to survive (IPCC, 1998). However, research has shown that most plant species are able to migrate at only $1 / 10^{\text {th }}$ of the speed required to keep up with human-induced climate change. It is important to take into consideration all other factors in addition to climate change that may hinder range shifts of organisms. Such barriers could be natural physical barriers such as mountain ranges or man-made settlements. When settlements are spread widely with dense population, habitat for colonization cease to exist. On the other hand, there could be limitations of nutrients and food or uncongenial environment for species to migrate and establish.

Fire, pests and diseases: Climate change has increased the extent of insect outbreaks through a combination of elevated plant drought stress, greater insect overwinter survival, and shortened insect development and reproduction cycles (Raffa et al., 2008). Warmer and drier conditions lead to more extensive and severe wildfires. Collectively, these disturbances could cause widespread reductions in forest productivity, greater tree mortality, and increased opportunities for colonization by plants that initiate changes in ecosystem state.

In India, where forests are already a scarce resource and there are multiple pressures on forest resources for biomass and grazing requirements as well as for providing habitat to the diverse flora and fauna, thereby maintaining biodiversity and ecosystem structure, an incidence of fire, pest and diseases could lead to loss of not only biodiversity, but also habitat and food availability to wildlife and a disruption of the flow of ecosystem services, thereby impacting the ecosystem itself as well as communities dependent on the resource. 
Wildlife: Existence of wildlife is dependent on presence of a healthy habitat that has adequate food, water and also can support new life. Further, appropriate temperature and moisture is also important for wildlife to thrive. Climate change is projected to lead to warming and affect food, water and habitat quality and availability. Under such conditions, species may not be able to adapt to climate change that is happening at a faster pace over the decades or to move fast enough to more suitable areas as their current areas become less suitable for them.

Invasive species: As temperature, precipitation, and other conditions change, the species best suited to the new conditions will thrive, often taking food and resources away from others. Some of the species that thrive might be invasive (not native to a region) and could gradually drive out or even kill native species. The impact of climate change and rising average temperatures can have a profound influence on species' geographical ranges and climate change is altering temperature and precipitation, the frequency of extreme weather events, as well as atmospheric composition and land cover (Dukes \& Mooney, 1999; Simberloff, 2000).

Climate change will alter habitats thereby increasing vulnerability as a result of resource scarcity and increased competition among species, to invasion. Due to their effects on ecosystems, invasions not only threaten biological diversity, but also affect human livelihoods in many ways. They can disrupt ecosystems, damaging the services they provide to humans, limiting access to food and water for local communities (Vilà et al., 2010).

Forest product flow and related livelihoods: Adaptation in the forest sector is crucial since local communities rely heavily on forests for their livelihood and since the impacts of climate change on forests, such as loss of biodiversity, are irreversible. Climate change has consequences on species survival and ecosystem functioning and flow of services, including forest products. This has implications for forest dependent populations, which depend on forests primarily for fuelwood and grazing purposes.

As discussed in the previous sections, there are no dedicated forest policies and programmes to address the issue of climate change. Further some of the consequences of climate change, are not addressed even indirectly by any of the programmes and policies that exist today. There is therefore a need to formulate dedicated policies and programmes to address the issue of climate change and help forest ecosystems and communities adapt to climate variability and long-term climate change.

Adaptation measures for forest ecosystems could be unplanned and reactive or planned. Planned adaptation requires redefining the goals and practices of forestry in anticipation of climate change-related risks and uncertainties. It is mostly medium and long-term and involves deliberate, anticipatory interventions at different levels and across sectors. It is interesting to note that the forest policies and programme, although mandated with the primary goal of conservation, catering to biomass requirements of a growing population and improved 
forest cover have positive implications for adaptation. To conclude, the Indian Forest Acts and Policies currently in place and the programmes being implemented and those envisaged have elements/features and activities that directly or indirectly contribute positively towards adaptation. However, there are some programmes which if implemented without adoption of certain precautionary principles would increase the vulnerability of forest ecosystems as discussed in the earlier sections. There are also certain consequences of climate change that are left unaddressed which could exacerbate the current pressure on forests and also put at risk the lives and livelihoods by way of increasing human-wildlife conflict as a result of range shifts, habitat destruction and disruption of food chains.

\section{Conclusion}

It is evident from the previous sections that to ensure the forest ecosystems is resilient to a changing climate and the flow of ecosystem services, particularly the forest products to the forest-dependent communities, there is a need for planned adaptation. Currently what are being achieved or realized are incidental and a co-benefit. Further, there are difficulties in law enforcement in the forest sector at times not due to lack of a policy and legal framework, but primarily due to gaps in implementation, limited capacity and insufficient funds and manpower.

There is thus a need for a clear strategy to ensure forest ecosystems and the ecosystem services flowing from the sector are not compromised. Further, with local communities' dependent on the forest ecosystems for many of their biomass requirements, waiting for the best science to emerge for taking action will lead to collapse of some of the forest ecosystems and therein the related livelihoods and local economy.

In conclusion, it may be stated that many existing policies may not directly hinder adaptation but, without a deliberate review, they also will not encourage adaptation. The need of the hour is to build in "adaptation friendly" provisions across the multiple policies that affect forest management. Various activities to be initiated for mainstreaming adaptation in current policies and programmes span the following broad areas:

- Formulation of dedicated and pro-active policies and programmes to address the issue of climate change. It is desirable to develop a forest policy or road map.

- Integration of forest issues into overall adaptation strategies.

- Planning, prioritizing and implementing adaptation actions in specific projects and programmes.

- Impact, vulnerability and adaptation assessments, including assessments of financial needs as well as economic, social and environmental costs and benefits of adaptation options.

- Enhance inter-sectoral coordination and dovetailing of inter-sectoral or inter-programme and scheme and department funds.

- Enhanced law enforcement and transparency. 
- Application of ecosystem vulnerability assessments and ecosystem-based adaptation approaches for setting priorities for action and for saving costs, since ecosystem approaches are often less cost-intensive and more likely to create "win-win" situations.

- Linking adaptation with mitigation measures.

- Empower traditional and indigenous communities.

- Promotion of economic valuation of forest ecosystem services.

- Monitoring and evaluation of adaptation measures.

- Capacity development of institutions.

Improve research and systematic observation for climate data collection, archiving, analysis and modelling for realistic climatic-related outputs at national and regional levels.

\section{Conflicts of Interest}

The authors declare no conflicts of interest regarding the publication of this paper.

\section{References}

ACT (2016). Forests and Natural Ecosystem Policies and Programmes: Implications for Adaptation under a Changing Climate. ACT Report, October 2016.

Betts, R. A., Sanderson, M., \& Woodward, S. (2008). Effects of Large-Scale Amazon Forest Degradation on Climate and Air Quality through Fluxes of Carbon Dioxide, Water, Energy, Mineral Dust and Isoprene. Philosophical Transactions of the Royal Society B, 363, 1873-1880. https://doi.org/10.1098/rstb.2007.0027

CBD (2018). Guidelines for Ecosystem-Based Approaches to Climate Change Adaptation and Disaster Risk Reduction.

Dukes, J. S., \& Mooney, H. A. (1999). Does Global Change Increase the Success of Biological Invaders? Trends in Ecology \& Evolution, 14, 135-139.

https://doi.org/10.1016/S0169-5347(98)01554-7

Gyampoh, B. A., Amisah, S., Idinoba, M., \& Nkem, J. (2009). Using Traditional Knowledge to Cope with Climate Change in Rural Ghana. Unasylva, 60, 70-74.

IPCC (1998). The Regional Impacts of Climate Change: An Assessment of Vulnerability. Cambridge: Cambridge University Press.

IPCC (2007). Summary for Policymakers. In M. L. Parry, O. F. Canziani, J. P. Palutikof, P. J. van der Linden, \& C. E. Hanson (Eds.), Climate Change 2007: Impacts, Adaptation and Vulnerability (pp. 7-22). Contribution of Working Group II to the Fourth Assessment Report of the Intergovernmental Panel on Climate Change, Cambridge: Cambridge University Press.

IPCC (2014). Summary for Policymakers. In C. B. Field, V. R. Barros, D. J. Dokken, K. J. Mach, M. D. Mastrandrea, T. E. Bilir, M. Chatterjee, K. L. Ebi, Y. O. Estrada, R. C. Genova, B. Girma, E. S. Kissel, A. N. Levy, S. MacCracken, P. R. Mastrandrea, \& L. L. White (Eds.), Climate Change 2014: Impacts, Adaptation, and Vulnerability, Part A: Global and Sectoral Aspects (pp. 1-32). Contribution of Working Group II to the Fifth Assessment Report of the Intergovernmental Panel on Climate Change, Cambridge: Cambridge University Press.

Lovejoy, T. E., \& Hannah, L. (2005). Climate Change and Biodiversity. New Delhi: TERI 
Press.

MoEF (2010). Climate Change and India: A $4 \times 4$ Assessment: A Sectoral and Regional Analysis for 2030s. New Delhi: Ministry of Environment and Forests, Government of India.

Poffenberger, M., \& Singh, C. (1996). In M. Poffenberger, \& B. Mcgean (Eds.), Village Voices Forest Choices-Joint Forest Management in India. New Delhi: Oxford University Press.

Raffa, K. F., Aukema, B. H., Bentz, B. J. et al. (2008). Cross-Scale Drivers of Natural Disturbances Prone to Anthropogenic Amplification: The Dynamics of Bark Beetle Eruptions. BioScience, 58, 501-517. https://doi.org/10.1641/B580607

Ravindranath, N. H., Sukumar, R., \& Deshingkar, P. (1997). Climate Change and Forests: Impacts of Adaptation. Stockholm: SEI.

Saxena, N. C. (1997). Saga of Participatory Forest Management. Bogor: CIFOR. https://doi.org/10.17528/cifor/000090

Seabauer (1992). Review of Social Forestry Programmes in India. Michelstadt: GWB Gesselschaft Fur Walderhaltung und Waldbewirtschaftung GMBH.

Simberloff, D. (2000). Global Climate Change and Introduced Species in United States Forests. The Science of the Total Environment, 262, 253-261. https://doi.org/10.1016/S0048-9697(00)00527-1

Stern, N. (2006). Stern Review on the Economics of Climate Change. Cambridge: Cambridge University Press. https://doi.org/10.1017/CBO9780511817434 http://mudancasclimaticas.cptec.inpe.br/ rmclima/pdfs/destaques/sternreview_report _complete.pdf

Thompson, I., Mackey, B., McNulty, S., \& Mosseler, A. (2009). Forest Resilience, Biodiversity, and Climate Change. A Synthesis of the Biodiversity/Resilience/Stability Relationship in Forest Ecosystems (Technical Series No. 43, 67 p). Montreal: Secretariat of the Convention on Biological Diversity.

UNFCCC (2015). https://unfccc.int/sites/default/files/english_paris_agreement.pdf

US-EPA (2010).

http://www3.epa.gov/climatechange/Downloads/Climate_Change_Ecosystems.pdf

Vilà, M., Basnou, C., Pyšek, P., Josefsson, M., Genovesi, P., Gollasch, S., Nentwig, W., Olenin, S., Roques, A., Roy, D., Hulme, P. E., \& DAISIE Partners (2010). How Well Do We Understand the Impacts of Alien Species on Ecosystem Services? A Pan-European, Cross-Taxa Assessment. Frontiers in Ecology and the Environment, 8, 135-144. https://doi.org/10.1890/080083

World Economic Forum (2016). The Global Risks Report 2016 (11th ed.). 